\title{
CONFERENCE ON THE DEVELOPER CONTRACT AND OTHER MEANS OF PURChasers' Rights PROTECTION (WROCLAW, 14 JUNE 2013)
}

\author{
MAREK LEŚNIAK*
}

The conference on the developer contract and other means of protecting purchasers' rights took place at the Faculty of Law, Administration and Economics of Wrocław University on 14 June 2013. The conference was organized by the Commercial and Economic Law Department. The National Notary Council, Notary Chamber in Wrocław, Association of Notaries of the Republic of Poland, Polish Developers' Association, Foundation for Safer Legal Transactions, the Rector of Wrocław University Professor Marek Bojarski and the Dean of Faculty of Law, Administration and Economics of Wrocław University Professor Włodzimierz Gromski provided their honorary patronage. The monthly publication "Rejent" and LexisNexis Polska provided media patronage for the conference.

The main objective of the conference's organizers and patrons was to present and analyze the Act on the protection of rights of purchasers of residential dwellings and detached houses of 16 September 2011 (Dz. U. no. 232 , item 1377). As the act came into force a year ago, it was possible to present and discuss the developer contract as a notary deed in practice, as well as court decisions issued on the basis of the Act's provisions. University researchers, teachers and postgraduate research assistants from twelve universities, as well as notaries, judges, attorneys and assistants participated in the conference.

Professor Karol Kiczka, Vice-Rector of Wrocław University, Professor Piotr Machnikowski, Deputy Dean of the Faculty of Law, Administration and Economics of Wrocław University, Lech Borzemski, the Chairman of the Board of the Notaries Chamber in Wroclaw, notary Zbigniew Klejment, the President of the Foundation for Safer Legal Transactions, notary Wojciech Fortuński, a member of the the National Notary Council, Konrad Płochocki, deputy director of the Polish Developers' Association and Professor Józef Frąckowiak, the head of the

DOI: $10.2478 /$ wrlae-2014-0106

* Dr Marek Leśniak, assistant professor at the Commercial and Economic Law Department, Faculty of Law, Administration and Economics of Wrocław University, a notary in Wrocław, contact at lesniak@prawo.uni.wroc.pl. 
Commercial and Economic Law Department, greeted the participants. Introductory lectures given by Professor Wojciech J. Katner (University of Łódź, the Supreme Court judge), Professor Jerzy Pisuliński (Jagiellonian University, Vice-Chair of the Civil Law Codification Commission), Professor Rafał Adamus (Opole University) and Dr. hab. Witold Srokosz (Wrocław University) opened the conference session.

Professor Wojciech J. Katner stated that the Act on the protection of rights of purchasers of residential dwellings and detached houses was undoubtedly necessary, but he questioned the current form of the Act, asking whether it fulfills its function. Professor Katner sought to determine whether this Act regulates a new type of nominate contract, i.e. the developer contract, or if it only protects the purchaser. In his opinion the developer contract is a nominate contract, and the construction, separation and transfer of property rights to the purchaser conducted by the developer constitutes the essentialia negotii of this agreement. On the other hand, Professor Jerzy Pisuliński claimed that the developer contract is a contract of sale, as demonstrated by many provisions of the Act. According to Professor Pisuliński, the developer contract is a binding agreement that obliges the developer to transfer property rights in exchange for monetary consideration. This binding character of the developer contract, particularly in case of a residential dwelling, results from the necessity of inter alia identifying the shares in jointly owned property or the basis of such identification.

The following paper, presented by Professor Rafał Adamus, focused on the characteristics of regulations for special bankruptcy proceedings applicable to developers. The author presented his doubts in conjunction with current regulations. He also pointed out that separate bankruptcy proceedings should apply to individuals who entered into invalid developer contracts. His presentation included opinions on the fate of developer contracts which had not been executed at the time of a bankruptcy announcement. Issues concerning a separate bankruptcy estate for developers and the role of purchasers' associations were also discussed. The final lecture was given by Dr hab. Witold Srokosz, who presented the advantages and disadvantages of regulations concerning housing trusts, bank guarantees and insurance guarantees present in the Act on the protection of rights of purchasers of residential dwellings and detached houses. Participants were then invited to a coffee break where they could discuss the issues presented during the first part of the conference. After the break, the conference's moderators, Dr Maciej Skory and Dr Marek Leśniak from Wrocław University, held a breakout session. Participants expressed opinions, presented comments and hypotheses while trying to answer questions, solve problems and clear up interpretational doubts.

Dr Marek Leśniak (Wrocław University), the conference's initiator, opened the session. The discussion was continued by Professor Edward Gniewek (Wrocław University), Dr Bartłomiej Gliniecki (Gdańsk University), Dr Adam Bieranowski (Warmia-Mazury University), Professor Jacek Górecki (Silesian University), notary Krzysztof Maj (Notary Chamber in Kraków), Przemysław Filipowicz (Catholic University of Lublin), Michał 
Hałasa (Catholic University of Lublin), Konrad Płochocki (Polish Developers' Association), Professor Aleksander Kappes (University of Łódź), Jerzy Pałys (official receiver in bankruptcy), Dr Piotr Wiórek (Wrocław University), Dr Jan Lic (University of Economics in Kraków), Professor Antoni Witosz (Silesian University) and notary Wojciech Fortuński (National Notary Council).

At the end, Professor Jerzy Pisuliński, Dr hab. Rafał Adamus and Dr hab. Witold Srokosz summarized the discussion. Professor Józef Frąckowiak, the head of the Commercial and Economic Law Department, closed the conference, declaring that "the law both as codified and as applied should be fair and just." He ended by thanking the participants and invited them to lunch.

The conference attracted numerous participants who held long and heated discussions on the provisions of the Act on the protection of rights of purchasers of residential dwellings and detached houses, considering both theoretical and practical aspects. In the face of differences in opinion regarding assessment of the developer contract, the participants agreed to disagree.

We hope that the Wrocław meeting will contribute to better application of the Act's provisions, as well as to preparation of legislative solutions that will eliminate current interpretational doubts. 